\title{
Phosphonated Carbocyclic 2'-Oxa-3'-azanucleosides as New Antiretroviral Agents
}

Ugo Chiacchio, ${ }^{\dagger}$ Antonio Rescifina, ${ }^{\dagger}$ Daniela Iannazzo, ${ }^{\#}$ Anna Piperno, ${ }^{\#}$ Roberto Romeo, ${ }^{\#}$ Luisa Borrello, ${ }^{\dagger}$

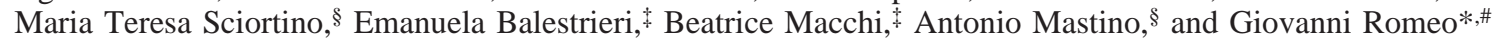

Dipartimento Farmaco-Chimico, Università di Messina, Via SS. Annunziata, Messina 98168, Italy, Dipartimento di Scienze Chimiche, Università di Catania, Viale Andrea Doria 6, Catania 95125, Italy, Dipartimento di Neuroscienze, Università di Roma "Tor Vergata", Via Montpellier 1, and IRCCS S. Lucia, Roma 00133, Italy, and Dipartimento di Scienze Microbiologiche, Genetiche e Molecolari, Università di Messina, Salita Sperone 31, Messina 98168, Italy

Received March 12, 2007

Phosphonated carbocyclic 2'-oxa-3'-azanucleosides have been synthesized and tested for their antiretroviral activity. The obtained results have shown that some of the compounds were as powerful as azydothymidine in inhibiting the reverse transcriptase activity of the human retrovirus T-cell leukemia/lymphotropic virus type 1 and in protecting human peripheral blood mononuclear cells against human retrovirus T-cell leukemia/ lymphotropic virus type 1 transmission in vitro. These data indicate that phosphonated carbocyclic $2^{\prime}$-oxa$3^{\prime}$-azanucleosides possess the necessary requirements to efficiently counteract infections caused by human retroviruses.

\section{Introduction}

Modification of naturally occurring nucleosides is an important research area for the development of new antiretroviral agents. ${ }^{1}$ In particular, heterocyclic replacement of the ribose moiety has resulted in the synthesis of new effective anti-HIV drugs. ${ }^{2,3}$ Recently, we have reported the synthesis of a series of nucleoside analogues where the furanose ring has been replaced by a N,O-heterocyclic system. ${ }^{4}$ The carbocyclic 2 oxa-3'-azanucleosides are endowed with interesting physiological activities. In particular, the fluorouracil analogue (ADF, Figure 1) is characterized by low cytotoxicity and, noteworthy, has been shown to specifically induce remarkable levels of apoptosis on lymphoid and monocytoid cells. ${ }^{4}$

Most of the nucleoside analogues possessing antiviral activities rely on phosphorylation by specific kinases; moreover, in many cases, among the three successive phosphorylation steps, the first is rate-limiting. ${ }^{5,6}$ On this basis, phosphate analogues, where the phosphate moiety is changed to isosteric and isoelectronic phosphonates, have been designed; these compounds mimic the nucleoside monophosphates and are able to bypass the initial selective enzymatic monophosphorylation step. $^{7}$

Accordingly, we have developed the transformation of the first-generation N,O-nucleosides $\mathbf{1}^{8}$ into the phosphonated nucleosides $\mathbf{2}$ and $\mathbf{3}$ (Figure 1) via the 1,3-dipolar cycloaddition of phosphonated nitrones with suitable dipolarophiles. The obtained compounds have proven to be potential antiretroviral agents: pyrimidine N,O-nucleosides exerted a specific inhibitory activity on two different types of commercial RT, ${ }^{a}$ from animal

* To whom correspondence should be addressed. Phone: +39090 356230. Fax: +390906766562. E-mail: gromeo@unime.it.

¿ Università di Catania.

\# Dipartimento Farmaco-Chimico, Università di Messina.

$\S$ Dipartimento di Scienze Microbiologiche, Genetiche e Molecolari, Università di Messina.

† Università di Roma "Tor Vergata" and IRCCS S. Lucia.

a Abbreviations: PCOANs, phosphonated carbocyclic 2'-oxa-3'-azanucleosides; RT, reverse transcriptase; HTLV-1, human retrovirus T-cell leukemia/lymphotropic virus type 1; AZT, azydothymidine; PBMCs, peripheral blood mononuclear cells; MRTIC, minimal RT inhibitory concentration; MPC, minimal protective concentration; $\mathrm{GIC}_{25}$, growth inhibitory concentration $25 \%$; $\mathrm{CC}_{20}$, cytotoxic concentration $20 \%$; RNIC, RNA inhibitory concentration.

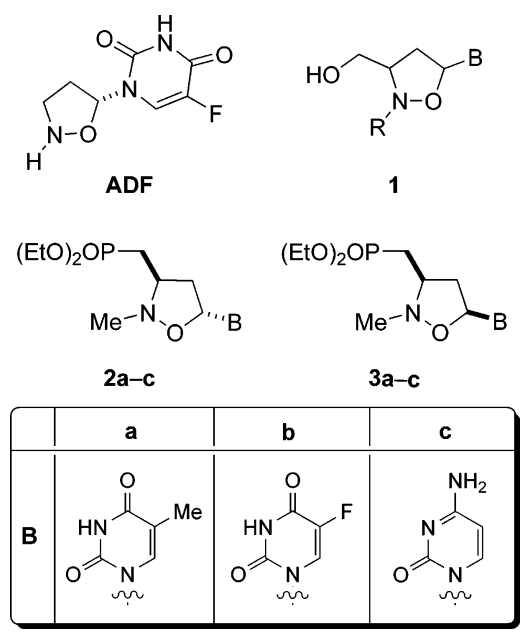

Figure 1. Nucleoside analogues.

retroviruses, comparable with that of the well-known AZT, following incubation with human PBMCs crude extract. ${ }^{4}$

Starting from these findings, to acquire more insight into the physiological properties of this class of compounds and also to obtain derivatives that could be more potent and more active against different virus strains, we have extended our studies to the synthesis and biological evaluation of 5-bromouracil, adenine, and guanine derivatives of this second generation of PCOANs. At the same time, a new and feasible synthetic route toward phosphonated pyrimidine and purine N,O-nucleosides has been designed.

Moreover, we extended our biological assays to understand whether PCOANs actually possess the necessary requirements for efficiently inhibiting the transmission of a human retrovirus. In this paper we report that PCOANs were able not only to inhibit the RT enzymatic activity of HTLV-1, the first identified human retrovirus, ${ }^{9}$ but also to efficiently protect human PBMCs from HTLV-1 infection in culture.

\section{Results and Discussion}

In the first attempt, the synthesis of $\mathbf{2} \mathbf{d}-\mathbf{f}$ and $\mathbf{3 d}-\mathbf{f}$ was performed according to the procedure previously reported for $\mathbf{2} \mathbf{a}-\mathbf{c}$ and $\mathbf{3 a}-\mathbf{c}{ }^{4}$ Thus, phosphonated nitrone $\mathbf{4}$ was reacted 
Scheme 1. Synthesis of Phosphonated N,O-Nucleosides 2e and 3d-f

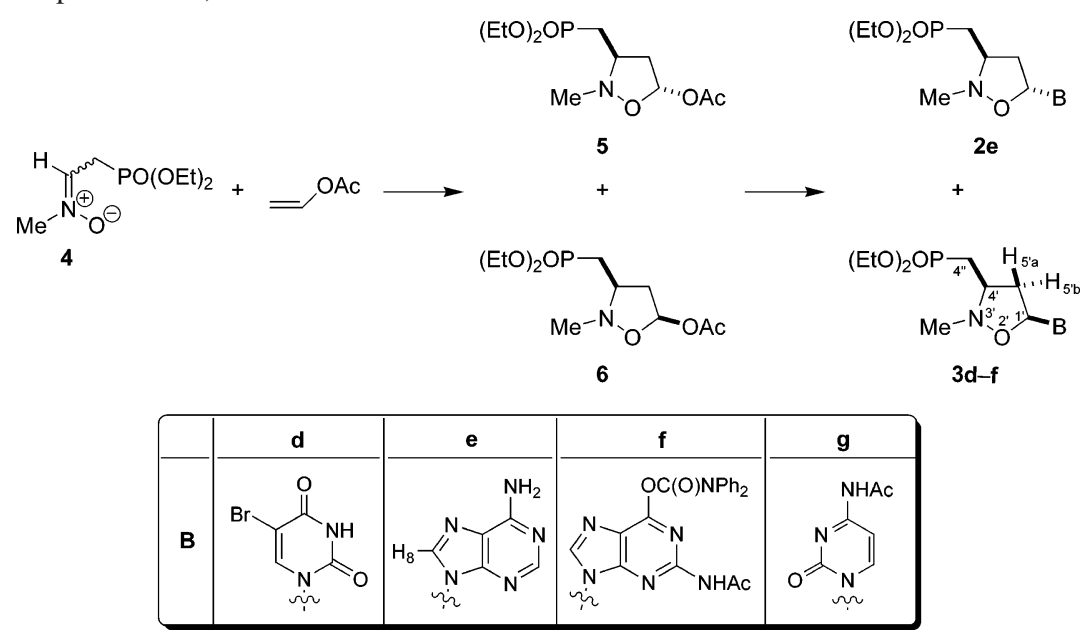

with vinyl acetate to give a mixture of epimeric isoxazolidines 5 and $\mathbf{6}$ (Scheme 1) in a 1:2.6 relative ratio (global yield 90\%).

The mixture of the two cycloadducts was coupled with silylated 5-bromouracil, adenine, and 2- $\mathrm{N}$-acetyl-6-O-(diphenylcarbamoyl)guanine in acetonitrile at $55^{\circ} \mathrm{C}$ in the presence of 0.4 equiv of TMSOTf as catalyst. The nucleosidation proceeded with good yield and complete selectivity, with respect to the anomeric center, for bromouracil derivative (3d was the exclusive adduct with $74 \%$ yield) and with moderate yields and poor selectivity for purine derivatives $\mathbf{e}$ and $\mathbf{f}$. So with adenine, $\alpha$ - and $\beta$-anomers $\mathbf{2 e}$ and $\mathbf{3 e}$ have been obtained in a relative ratio 1:1.5 (total yield 52\%), while for guanine, the ${ }^{1} \mathrm{H}$ NMR spectrum of the crude reaction mixture showed the presence of both $\alpha$-and $\beta$-anomers, but only the $\beta$-anomer $\mathbf{3 f}$ has been isolated after flash chromatography in very poor yield (15\%). In this last case, nucleosides $\mathbf{2} \mathbf{f}$ and $\mathbf{3 f}$ appeared to be unstable; they decomposed easily by cleavage of the glycoside bond and release of the nucleoside base together with the formation of decomposition products.

The stereochemistry of the obtained derivatives $\mathbf{2 e}$ and $\mathbf{3 d}-\mathbf{f}$ was achieved by NOE measurements (see Supporting Information).

A successful implementation of the synthetic scheme has been achieved by the use of the $C$-[(tert-butyldiphenylsilyl)oxy]- $N$ methylnitrone $7:{ }^{10}$ the cycloaddition reaction with vinyl acetate, in anhydrous ether at room temperature, proceeded with a good stereoselectivity affording a mixture of epimeric isoxazolidines 8 and $\mathbf{9}$ (Scheme 2) in a relative ratio 1:4.2 (global yield 90\%) as determined by ${ }^{1} \mathrm{H}$ NMR analysis.

The stereochemical outcome of the cycloaddition process can be explained by considering that nitrone 7 has been shown by ${ }^{1} \mathrm{H}$ NMR and NOE data to be the $Z$ isomer; ${ }^{10}$ thus, the major product 9 could be formed by the $Z$ nitrone reacting in an exo mode. The crude mixture of isoxazolidines was nucleosidated with pyrimidine and purine bases. The pyrimidine nucleosidation was performed with silylated nucleobases in acetonitrile at $50{ }^{\circ} \mathrm{C}$ in the presence of 0.4 equiv of TMSOTf as catalyst. The reaction, carried out with silylated thymine, 5-fluorouracil, 5-bromouracil, and $N$-acetylcytosine, proceeded with a satisfactory selectivity to give a mixture of $\alpha$ - and $\beta$-nucleosides $\mathbf{1 0 a}, \mathbf{b}, \mathbf{d}, \mathbf{g}$ and 11a,b,d,g in a 3:7 relative ratio (global yield 8590\%, Scheme 2).

Compounds 10a,b,d,g and 11a,b,d,g were separated by flash chromatography (98:2 chloroform/methanol as eluant), and the relative configuration was assigned by NOE measurements. In particular, for $\beta$-derivative 11a, the positive NOE effect observed
Scheme 2. Synthesis of Phosphonated N,O-Nucleosides 2a-e and $3 \mathbf{a}-\mathbf{e}^{a}$
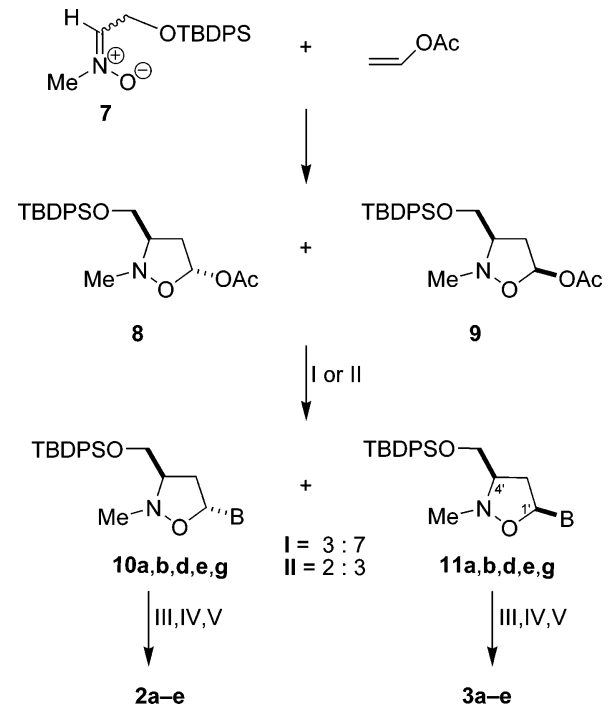

${ }^{a}$ (I) Silylated nucleobase, MeCN, TMSOTf; (II) 6-bromopurine, DBU, TMSOTF, then $\mathrm{NH}_{3} / \mathrm{MeOH}$; (III) TBAF, THF; (IV) TSCl, Et ${ }_{3} \mathrm{~N}, \mathrm{DCM}$; (V) $(\mathrm{EtO})_{3} \mathrm{P}$.

for $\mathrm{H}_{4^{\prime}}$ when irradiating $\mathrm{H}_{1^{\prime}}$ is clearly indicative of the cis configuration of the substituents at $\mathrm{C}_{1^{\prime}}$ and $\mathrm{C}_{4^{\prime}}$.

The purine nucleosidation for the adenine derivative was performed with 6-bromopurine in acetonitrile with DBU at $60{ }^{\circ} \mathrm{C}$ in the presence of 4 equiv of TMSOTf as catalyst. The reaction proceeded with good yield to give, after in situ treatment with ammoniacal methanol, a mixture of $\alpha$ - and $\beta$-nucleosides 10e and 11e in a 2:3 relative ratio (global yield 75\%, Scheme 2). Compounds were separated and identified as reported above.

Transformation of the nucleosides $\mathbf{1 0}$ and $\mathbf{1 1}$ into the corresponding phosphonates $\mathbf{2}$ and $\mathbf{3}$ was finally performed by desilylation, tosylation, and subsequent Arbuzov reaction with triethyl phosphite.

Biological Tests. Antiretroviral Activity. For testing the potential activity of PCOANs against human retroviruses, first we determined their ability to inhibit HTLV-1 reverse transcriptase activity in vitro, by means of a cell-free assay recently described by us. ${ }^{11}$ The results were expressed as MRTIC. Identical results were obtained in three different experiments (Table 1). Most of the newly synthesized compounds, following activation through preincubation with a crude extract of PHAstimulated PBMCs, caused complete inhibition of HTLV-1 RT 
Table 1. Inhibitory Activity and Cytotoxicity for Compounds $2 \mathbf{e}$ and $3 \mathbf{a}-\mathbf{e}$

\begin{tabular}{|c|c|c|c|c|}
\hline compd & $\begin{array}{l}\text { HTLV-1-RT }^{a} \\
\text { MRTIC, }{ }^{n M}\end{array}$ & $\begin{array}{c}\text { anti-HTLV-1 assay }^{b} \\
\text { MPC, } \mu \mathrm{M}\end{array}$ & $\begin{array}{l}\mathrm{GIC}_{25}{ }^{c} \mu \mathrm{M} \\
\text { (Pearson's } r \text { ) }\end{array}$ & $\mathrm{CC}_{20},{ }^{d} \mu \mathrm{M}$ \\
\hline 3a & 0.6 & 1 & $817(0.88)$ & $>2048$ \\
\hline $3 b$ & 0.6 & 1 & $119(0.99)$ & $>2048$ \\
\hline $3 c$ & 0.6 & 1 & $56(0.98)$ & $>2048$ \\
\hline 3d & 8 & $>100$ & $215(0.94)$ & $>2048$ \\
\hline $3 e$ & 0.6 & 5 & $39(0.92)$ & $>2048$ \\
\hline $2 e$ & $>10^{4}$ & $>100$ & $121(0.83)$ & $>2048$ \\
\hline AZT & 4 & 1 & $15(0.91)$ & 1153 \\
\hline
\end{tabular}

${ }^{a}$ MRTIC toward HTLV-1-RT, determined as the minimal concentration required to completely inhibit reverse transcription evaluated in a cell-free assay by a RT-PCR assay through an amplification program of 20 cycles. ${ }^{b}$ MPC determined as the minimal concentration of the compounds required to completely protect PBMCs from HTLV-1 transmission, as revealed by inhibition of Tax/Rex viral mRNA expression, evaluated by liquid hybridization assay, at 3 weeks after exposure to the virus in the presence or the absence of PCOANs. ${ }^{c}$ Compound concentration required to cause $\mathrm{GIC}_{25}$, evaluated by living cell count using trypan blue exclusion test in uninfected PBMCs after 1 week of culture. ${ }^{d} \mathrm{CC}_{20}$ evaluated by trypan blue exclusion test in uninfected PBMC after 1 week of culture.

activity at $0.6 \mathrm{nM}$, except for $\mathbf{3 d}$, which was efficient at $8 \mathrm{nM}$, and $\mathbf{2 e}$, which was not active. Interestingly, most of the new compounds showed an activity higher than that of AZT in inhibiting HTLV-1 RT, following a similar activation.

Different concentrations of PCOANs and of the reference compound AZT were next tested for their ability to protect human PBMCs from HTLV-1 infection when added immediately before virus exposure to the cultures using an in vitro protection assay. ${ }^{11,12}$ Differently from HIV, HTLV-1 does not cause any cytopathic effect following infection but rather stimulates proliferation of infected cells and eventually immortalizes them. Thus, at 3 weeks in culture after infection, the presence of HTLV-1 proviral DNA and the expression of viral RNA were detected by DNA-PCR of a specific HTLV-1 pol gene sequence and by RT-PCR for the Tax/Rex region of HTLV-1, respectively. The same concentration of the compounds equally inhibited or not inhibited proviral DNA presence and viral RNA expression. To avoid useless duplication of data, proviral DNA results are omitted. Results, expressed as the minimal concentration required to fully protect cell cultures from HTLV-1 transmission, showed that $\mathbf{3 a}, \mathbf{3 b}, \mathbf{3 c}$, and AZT fully inhibited HTLV-1-RNA expression equally at 100, 25, 5, and $1 \mu \mathrm{M}$, respectively, while $3 \mathrm{e}$ was inhibitory at 100,25 , and 5 $\mu \mathrm{M}$ but not at $1 \mu \mathrm{M}$. Conversely, $3 \mathbf{d}$ and $2 \mathrm{e}$ were not able to protect against HTLV-1 infection even at the higher concentrations tested. Experiments were repeated three times, using PBMCs from three different donors, with identical results.

Cell Toxicity. Cell toxicity is a major limit for the utilization of nucleoside antiviral agents. Thus, freshly separated PBMCs were assayed for their growth and death during short-term culture in the presence of the newly synthesized compounds and of interleukin 2, without additional stimuli. The results obtained on day 7 in culture, expressed as $\mathrm{GIC}_{25}$ and $\mathrm{CC}_{20}$, respectively, indicate that most of the examined compounds were poorly cytostatic and very low or not at all cytotoxic in comparison with AZT (Table 1). Moreover, no evidence for induction of apoptosis by PCOANs, at the concentrations tested, was obtained (data not shown).

\section{Conclusions}

Phosphonated N,O-nucleosides have been synthesized in good yields by the 1,3-dipolar cycloaddition methodology according to two different routes, which exploit two different nitrones as starting material. The use of the $C$-[(tert-butyldiphenylsilyl)- oxy]- $N$-methylnitrone 7 has led to better yields with respect to the approach based on the phosphonated nitrone 4 .

Regarding to their antiretroviral action, 2e showed no activity. Conversely, 3d, although it inhibited RT activity in the cellfree assays as efficiently as AZT, was unable to protect against HTLV-1 infection in vitro, suggesting an impairment at cell entry or at metabolic biotransformation levels. Interestingly, all the other new compounds tested showed powerful antiretroviral activity not only in the cell-free assay but also in an experimental cell model of infection, suggesting that these compounds are converted properly to the phosphonic acid diphosphate RT inhibitors by cell kinases. However, in the present report we have not addressed the exact mechanism by which PCOANs exert RT inhibition. In particular, we have no information about whether they act as chain terminators, as it seems plausible. Future investigations on this point will clarify this aspect. Very important, toxicity toward lymphoid cells of the new compounds was remarkably lower than that of AZT. In conclusion, our results add new perspectives in the development if PCOANs as possible new pharmacological tools of intervention against infections sustained by human retroviruses.

\section{Experimental Section}

Compounds $\mathbf{2 a}, \mathbf{g}$ and $\mathbf{3 a}-\mathbf{c}, \mathbf{g}$ were previously reported. ${ }^{4}$ Compounds $\mathbf{2 e}$ and $\mathbf{3 d}-\mathbf{f}$ described in Scheme 1 have been synthesized according to the same procedure. ${ }^{4}$ Compounds $\mathbf{2} \mathbf{a}-\mathbf{e}$ and $\mathbf{3 a}-\mathbf{e}$ have also been prepared starting from nitrone 7 , according to Scheme 2 (see Supporting Information).

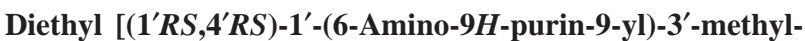
$\mathbf{2}^{\prime}$-oxa-3'-azacyclopent-4'-yl]methylphosphonate (2e). 2e was the second eluted product. Yield $20.8 \%$, sticky oil. ${ }^{1} \mathrm{H}$ NMR $(500 \mathrm{MHz}$, $\left.\mathrm{CDCl}_{3}\right): \delta 1.35(\mathrm{dt}, 6 \mathrm{H}, J=3.5$ and $7.1 \mathrm{~Hz}), 1.95(\mathrm{ddd}, 1 \mathrm{H}, J=$ 10.3, 15.0, $18.1 \mathrm{~Hz}, \mathrm{H}_{4}{ }^{\prime \prime}$ ), 2.15 (ddd, $1 \mathrm{H}, J=3.7,15.0,20.8 \mathrm{~Hz}$, $\left.\mathrm{H}_{4^{\prime \prime} \mathrm{b}}\right), 2.81$ (s, 3H, $\left.N-\mathrm{CH}_{3}\right), 2.87\left(\mathrm{~m}, 1 \mathrm{H}, \mathrm{H}_{5^{\prime}} \mathrm{a}\right), 3.13\left(\mathrm{~m}, 1 \mathrm{H}, \mathrm{H}_{5^{\prime} \mathrm{b}}\right)$, $3.54\left(\mathrm{~m}, 1 \mathrm{H}, \mathrm{H}_{4^{\prime}}\right), 4.18(\mathrm{~m}, 4 \mathrm{H}), 5.96\left(\mathrm{bs}, 2 \mathrm{H}, \mathrm{NH}_{2}\right), 6.32(\mathrm{~m}, 1 \mathrm{H}$, $\left.\mathrm{H}_{1^{\prime}}\right), 8.04\left(\mathrm{~s}, 1 \mathrm{H}, \mathrm{H}_{8}\right), 8.34\left(\mathrm{~s}, 1 \mathrm{H}, \mathrm{H}_{3}\right) .{ }^{13} \mathrm{C} \mathrm{NMR}(125 \mathrm{~Hz}$, $\left.\mathrm{CDCl}_{3}\right): \delta 16.4,16.45,26.6,29.3,41.8,43.7,61.9,62.1,63.3$, 81.9, 119.9, 138.9, 149.5, 153.0. HRMS (EI) calcd for $\left(\mathrm{M}^{+}\right)$ $\mathrm{C}_{14} \mathrm{H}_{23} \mathrm{~N}_{6} \mathrm{O}_{4} \mathrm{P}, 370.1518$. Anal. $\left(\mathrm{C}_{14} \mathrm{H}_{23} \mathrm{~N}_{6} \mathrm{O}_{4} \mathrm{P}\right) \mathrm{C}, \mathrm{H}, \mathrm{N}$.

Diethyl [(1'SR,4'RS)-1'-(5-Bromo-2,4-dioxo-3,4-dihydropyrimid1(2H)-yl-3'-methyl-2'-oxa-3'-azacyclopent-4' -yl]methylphosphonate (3d). Yield $74 \%$, sticky oil. ${ }^{1} \mathrm{H}$ NMR $\left(500 \mathrm{MHz}, \mathrm{CDCl}_{3}\right): \delta$ $1.34(\mathrm{dt}, 3 \mathrm{H}, J=4.9$ and $7.2 \mathrm{~Hz}), 1.35(\mathrm{dt}, 3 \mathrm{H}, J=4.9$ and 7.2 $\mathrm{Hz}$ ), 1.90 (ddd, $1 \mathrm{H}, J=9.9,14.9$, and $18.2 \mathrm{~Hz}, \mathrm{H}_{4^{\prime \prime}}$ ), 2.09 (m, $1 \mathrm{H}, \mathrm{H}_{4^{\prime \prime}} \mathrm{b}$ ), 2.32 (ddd, $1 \mathrm{H}, J=4.2,9.5$, and $14.0 \mathrm{~Hz}, \mathrm{H}_{5^{\prime} \mathrm{a}}$ ), 2.77 (s, $\left.3 \mathrm{H}, \mathrm{N}-\mathrm{CH}_{3}\right), 2.91\left(\mathrm{ddd}, 1 \mathrm{H}, J=7.8,9.5\right.$, and $\left.9.9 \mathrm{~Hz}, \mathrm{H}_{4^{\prime}}\right), 3.21$ (dt, $1 \mathrm{H}, J=7.8$ and $\left.14.0 \mathrm{~Hz}, \mathrm{H}_{5^{\prime} \mathrm{b}}\right), 4.12(\mathrm{~m}, 4 \mathrm{H}), 6.09$ (dd, $1 \mathrm{H}, J$ $=4.2$ and $\left.7.8 \mathrm{~Hz}, \mathrm{H}_{1^{\prime}}\right), 8.16\left(\mathrm{~s}, 1 \mathrm{H}, \mathrm{H}_{6}\right), 9.61(\mathrm{bs}, 1 \mathrm{H}, N \mathrm{H}),{ }^{13} \mathrm{C}$ NMR $\left(125 \mathrm{~Hz}, \mathrm{CDCl}_{3}\right): \delta 16.4,16.5,29.30,42.7,44.7,61.9,62.1$, 63.3, 83.0, 96.4, 140.0, 149.7, 159.4. HRMS (EI) Calcd for $\left(\mathrm{M}^{+}\right)$ $\mathrm{C}_{13} \mathrm{H}_{21} \mathrm{BrN}_{3} \mathrm{O}_{6} \mathrm{P}$, 425.0351. Anal. $\left(\mathrm{C}_{13} \mathrm{H}_{21} \mathrm{BrN}_{3} \mathrm{O}_{6} \mathrm{P}\right) \mathrm{C}, \mathrm{H}, \mathrm{N}$.

Diethyl [(1'SR,4'RS)-1'-(6-Amino-9H-purin-9-yl)-3'-methyl$\mathbf{2}^{\prime}$-oxa-3'-azacyclopent-4'-yl]methylphosphonate (3e). 3e was the first eluted product. Yield $31.2 \%$, sticky oil. ${ }^{1} \mathrm{H}$ NMR $(500 \mathrm{MHz}$, $\left.\mathrm{CDCl}_{3}\right): \delta 1.34(\mathrm{dt}, 6 \mathrm{H}, J=1.5$ and $7.1 \mathrm{~Hz}), 2.0(\mathrm{ddd}, 1 \mathrm{H}, J=$ $10.1,15.0$, and $18.1 \mathrm{~Hz}, \mathrm{H}_{4 \prime \prime}$ ), 2.13 (ddd, $1 \mathrm{H}, J=3.0,15.0$, and $20.5 \mathrm{~Hz}, \mathrm{H}_{4^{\prime \prime} \mathrm{b}}$ ), 2.67 (ddd, $1 \mathrm{H}, J=3.6,9.3$, and $14.0 \mathrm{~Hz}, \mathrm{H}_{5^{\prime} \mathrm{a}}$ ), $2.77\left(\mathrm{~s}, 3 \mathrm{H}, \mathrm{N}-\mathrm{CH}_{3}\right), 2.99$ (dddd, $1 \mathrm{H}, J=3.0,7.9,9.3$, and 10.1 $\mathrm{Hz}, \mathrm{H}_{4^{\prime}}$ ), 3.28 (ddd, 1H, J = 7.9, 8.1, $14.0 \mathrm{~Hz}, \mathrm{H}_{5^{\prime} \mathrm{b}}$ ), 4.09 (m, 4H), $6.14\left(\mathrm{bs}, 2 \mathrm{H}, \mathrm{NH}_{2}\right), 6.43\left(\mathrm{dd}, 1 \mathrm{H}, J=3.6\right.$ and $\left.8.1 \mathrm{~Hz}, \mathrm{H}_{1^{\prime}}\right), 8.31$ $\left(\mathrm{s}, 1 \mathrm{H}, \mathrm{H}_{8}\right), 8.32\left(\mathrm{~s}, 1 \mathrm{H}, \mathrm{H}_{3}\right) .{ }^{13} \mathrm{C} \mathrm{NMR}\left(125 \mathrm{~Hz}, \mathrm{CDCl}_{3}\right): \delta 16.4$, 16.5, 26.6, 29.6, 42.6, 43.6, 61.9, 62.1, 63.3, 80.2, 119.1, 149.5, 152.5, 155.2. HRMS (EI) calcd for $\left(\mathrm{M}^{+}\right) \mathrm{C}_{14} \mathrm{H}_{23} \mathrm{~N}_{6} \mathrm{O}_{4} \mathrm{P}, 370.1518$. Anal. $\left(\mathrm{C}_{14} \mathrm{H}_{23} \mathrm{~N}_{6} \mathrm{O}_{4} \mathrm{P}\right) \mathrm{C}, \mathrm{H}, \mathrm{N}$.

Diethyl [(1'RS,4'RS)-1'-(2-Acetamido-9H-purin-6-yldiphenylcarbamate)-9-yl-3'-methyl-2' -oxa-3' -azacyclopent-4' -yl]meth- 
ylphosphonate (3f). Yield 15\%, sticky oil. ${ }^{1} \mathrm{H}$ NMR $(500 \mathrm{MHz}$, $\left.\mathrm{CDCl}_{3}\right): \delta 1.34(\mathrm{dt}, 6 \mathrm{H}, J=2.6$ and $7.0 \mathrm{~Hz}), 1.96(\mathrm{ddd}, 1 \mathrm{H}, J=$ $10.2,14.7$, and $18.0 \mathrm{~Hz}, \mathrm{H}_{4 " \mathrm{a}}$ ), 2.11 (ddd, $1 \mathrm{H}, J=2.9,14.7$, and $20.5 \mathrm{~Hz}, \mathrm{H}_{4 \prime \prime}$ ), 2.54 (s, $\left.3 \mathrm{H}, \mathrm{C}(\mathrm{O}) \mathrm{CH}_{3}\right), 2.65$ (ddd, $1 \mathrm{H}, J=3.7$, 9.0, and $14.0 \mathrm{~Hz}, \mathrm{H}_{5^{\prime} \mathrm{a}}$ ), 2.75 (s, 3H, $\left.N-\mathrm{CH}_{3}\right), 2.98$ (dddd, $1 \mathrm{H}, J=$ $2.9,8.3,9.0$, and $\left.10.2 \mathrm{~Hz}, \mathrm{H}_{4^{\prime}}\right), 3.30$ (ddd, $1 \mathrm{H}, J=7.9,8.3,14.0$ $\left.\mathrm{Hz}, \mathrm{H}_{5^{\prime} \mathrm{b}}\right), 4.10(\mathrm{dq}, 4 \mathrm{H}, J=7.0$ and $10.8 \mathrm{~Hz}), 6.35(\mathrm{dd}, 1 \mathrm{H}, J=$ 3.7 and $\left.8.3 \mathrm{~Hz}, \mathrm{H}_{1^{\prime}}\right), 7.23-7.44(\mathrm{~m}, 10 \mathrm{H}), 7.45(\mathrm{bs}, 1 \mathrm{H}, \mathrm{NH}), 8.07-$ $(\mathrm{s}, 1 \mathrm{H}), 8.43(\mathrm{~s}, 1 \mathrm{H},) .{ }^{13} \mathrm{C} \mathrm{NMR}\left(125 \mathrm{~Hz}, \mathrm{CDCl}_{3}\right): \delta 16.3,16.3$, 24.0, 26.4, 43.2, 44.6, 49.2, 62.9, 63.1, 81.4, 116.1, 121.9, 127.0, 129.5, 140.6, 141.9, 144.8, 152.5, 153.9, 153.70, 170.0. HRMS (EI) calcd for $\left(\mathrm{M}^{+}\right), \mathrm{C}_{29} \mathrm{H}_{34} \mathrm{~N}_{7} \mathrm{O}_{7} \mathrm{P}$ 623.2257. Anal. $\left(\mathrm{C}_{29} \mathrm{H}_{34} \mathrm{~N}_{7} \mathrm{O}_{7} \mathrm{P}\right) \mathrm{C}$, $\mathrm{H}, \mathrm{N}$.

Acknowledgment. This work was partially supported by M.I.U.R. (Progetto P.R.I.N. 2005, 2006).

Supporting Information Available: Experimental details on the synthesis of the compounds described in this paper, spectral data for all relevant compounds, elemental analysis data of all compounds, and details of all biological methods. This material is available free of charge via the Internet at http://pubs.acs.org.

\section{References}

(1) (a) Jordheim, L. P.; Galmarini, C. M.; Dumontet, C. Recent Developments To Improve the Efficacy of Cytotoxic Nucleoside Analogues. Recent Pat. Anti-Cancer Drug Discovery 2006, 1, 163170. (b) Schinazi, R. F.; Hernandez-Santiago, B. I.; Hurwitz, S. J. Pharmacology of Current and Promising Nucleosides for the Treatment of Human Immunodeficiency Viruses. Antiviral Res. 2006, 71, 322-334. (c) Michael, J. O. New Nucleoside Reverse Transcriptase Inhibitors for the Treatment of HIV Infections. Curr. Opin. Pharmacol. 2004, 4, 431-436.

(2) (a) Choo, H.; Chen, X.; Yadav, V.; Wang, J.; Schinazi, R. F.; Chu, C. K. Synthesis and Anti-HIV Activity of D- and L-Thietanose Nucleosides. J. Med. Chem. 2006, 49, 1635-1647. (b) Chiacchio, U.; Corsaro, A.; Iannazzo, D.; Piperno, A.; Pistarà, V.; Rescifina, A.; Romeo, R.; Valveri, V.; Mastino, A.; Romeo, G. Enantioselective Syntheses and Cytotoxicity of $N, O$-Nucleosides. J. Med. Chem. 2003, 46, 3696-3702. (c) Lee, Y.-S.; Hyean, K. B. Heterocyclic Nucleoside Analogues: Design and Synthesis of Antiviral, Modified Nucleosides Containing Isoxazole Heterocycles. Bioorg. Med. Chem. Lett. 2002, 12, 1395-1397.

(3) Merino, P.; Franco, S.; Merchan, F. L.; Tejero, T. Recent Developments on Chemistry and Biological Activity of Nucleoside Analogues with an Extra Heteroatom in the Sugar Ring. Recent Res. Dev. Org. Chem. 2000, 4, 227-237.
(4) Chiacchio, U.; Balestrieri, E.; Macchi, B.; Iannazzo, D.; Piperno, A.; Rescifina, A.; Romeo, R.; Saglimbeni, M.; Sciortino, M. T.; Valveri, V.; Mastino, A.; Romeo, G. Synthesis of Phosphonated Carbocyclic-2'-oxo-3'-aza-nucleosides: Novel Inhibitors of Reverse Transcriptase. J. Med. Chem. 2005, 48, 1389-1394.

(5) Perigaud, C.; Girardet, J. L.; Gosselin, G.; Imbach, J. L. Comments on Nucleotide Delivery Forms. In Advances in Antiviral Drug Design; De Clercq, E., Ed.; JAI Press: Greenwich, CT, 1995; Vol. 2, pp 167-172.

(6) (a) Mitsuya, H.; Yarchoan, R.; Broder, S. Molecular Targets for Aids Therapy. Science 1990, 249, 1533-1544. (b) De Clercq, E. HIV Resistance to Reverse Transcriptase Inhibitors. Biochem. Pharmacol. 1994, 47, 155-169. (c) Katz, R. A.; Skalka, A. M. The Retroviral Enzymes. Annu. Rev. Biochem. 1994, 63, 133-173. (d) Turner, B. G.; Summers, M. F. Structural Biology of HIV. J. Mol. Biol. 1999. 285, 1-32. (e) Jonckheere, H.; Anne, J.; De Clercq, E. The HIV-1 Reverse Transcription (RT) Process as Target for RT Inhibitors. Med. Res. Rev. 2000, 20, 129-154.

(7) Mulato, A. S.; Cherrington, J. M. Anti-HIV Activity of Adefovir PMEA and PMPA in Combination with Antiretroviral Compounds: In Vitro Analyses. Antiviral Res. 1997, 36, 91-97.

(8) Chiacchio, U.; Corsaro, A.; Gumina G.; Rescifina, A.; Iannazzo, D.; Piperno, A.; Romeo, R.; Romeo, G. Homochiral $\alpha$-D- and $\beta$-DIsoxazolidinylthymidines via 1,3-Dipolar Cycloaddition. J. Org. Chem. 1999, 64, 9321-9327.

(9) Poiesz, B. J.; Ruscetti, F. W.; Reitz, M. S.; Kalyanaraman, V. S.; Gallo, R. C. Isolation of a New Type C Retrovirus (HTLV) in Primary Uncultured Cells of a Patient with Sezary T-Cell Leukaemia. Nature 1981, 294, 268-271.

(10) Iannazzo, D.; Piperno, A.; Pistarà, V.; Rescifina, A.; Romeo, R. Modified nucleosides. A general and diastereoselective approach to N,O-psiconucleosides. Tetrahedron 2002, 58, 581-587.

(11) Balestrieri, E.; Sciortino, M. T.; Mastino, A.; Macchi, B. Protective Effect of the Acyclic Nucleoside Phosphonate Tenofovir toward Human T-Cell Leukaemia/lymphotropic Virus Type 1 Infection of Human Peripheral Blood Mononuclear Cells in Vitro. Antiviral Res. 2005, 68, 154-162.

(12) (a) Macchi, B.; Balestrieri, E.; Mastino, A. Effects of NucleosideBased Anti-Retroviral Chemotherapy on Human T-Cell Leukaemia/ Lymphotropic Virus Type-1 (HTLV-1) Infection in Vitro. J. Antimicrob. Chemother. 2003, 51, 1327-1330. (b) Balestrieri, E.; Forte, G.; Matteucci, C.; Mastino, A.; Macchi, B. Effect of Lamivudine on Transmission of Human T-Cell Lymphotropic Virus Type 1 to Adult Peripheral Blood Mononuclear Cells in Vitro. Antimicrob. Agents Chemother. 2002, 46, 3080-3083. (c) Macchi, B.; Faraoni, I.; Zhang, J.; Grelli, S.; Favalli, C.; Mastino, A.; Bonmassar, E. AZT Inhibits the Transmission of Human T Cell Leukaemia/Lymphoma Virus Type I to Adult Peripheral Blood Mononuclear Cells in Vitro. $J$. Gen. Virol. 1997, 78, 1007-1016.

JM070285R 